UDK 782(497.4 Ljubljana)

Špela Lah

Filozofska fakulteta Univerze v Ljubljani

Philosophical Faculty, University of Ljubljana

\title{
Struktura repertoarja glasbeno-gledaliških del novega Deželnega gledališča (1892-1903)
}

\section{The Structure of the Musical Theatre Repertoire in the New Regional Theatre (1892-1903)}

Ključne besede: Deželno gledališče, Nemško gledališče, Slovensko gledališče, operne premiere

POVZETEK

Otvoritev nove stavbe Dežehnega gledališča, ki je luč sveta ugledala $v$ začetku sezone 1892/93, dobrega pol desetletja po uničujočem požaru, je pomenila zgodovinsko prelomnico $\mathrm{v}$ slovenski glasbenogledališki poustvarjalnosti. Temeljni kamen operni reprodukciji je slovensko gledališče postavilo sicer že leta 1889, prave pogoje za delo pa je vendarle dobilo šele pod streho novega gledališča, katerega si je delilo skupaj z nemškim vodstvom. Medtem ko so gostujoče nemške družine nadaljevale dolgoletno tradicijo gledaliških predstav, so Slovenci neobremenjeno začeli na samem začetku. Razlika med vodstvi se je pokazala že $v$ prvi sezoni delovanja. Nemci so repertoar prilagajali sposobnostim sezonskih izvajalcev in predvajali največkrat le malo opernih predstav (ali celo nobene), medtem ko so pri oblikovanju sporeda Slovenci dali glavno težo ravno operam.

Pričujoče besedilo se osredotoča na pro dekado delovanja novega Deželnega gledališča. Ločeno sledi najprej nemškemu, nato še slovenskemu
Keywords: Regional theatre, German theatre, Slovene theatre, opera premieres

\section{SUMMARY}

The opening of the new Regional Theatre at the beginning of the 1892/93 season, a full decade after the devastating fire, was a turning point in the performing history of the Slovene musical theatre. The foundation stone for operatic performances of the Slovene theatre was laid in 1889; however, adequate working conditions were given only under the roof of the new theatre building, which was to be shared with the German administration. Whereas guesting German thatre companies carried on with the longstanding tradition of theatrical performances, the Slovenes, from the very beginning, started unencumbered. The very first season revealed the difference. While the German side adjusted its repertoire to the abilities of seasonal performers, and gave only a few (or even no) operatic performances, the Slovenes, as regards their repertoire, attached special weight to operas. The present text focuses on the first decade of the new Regional Theatre's activities, commencing with the German repertoire, and, separately, dealing 
glasbenogledališkemu programu. V ospredju zanimanja so operne premiere na eni in drugi strani, pospremljene $z$ odzivi kritik $\mathrm{v}$ aktualnih lokalnih časopisih, kot sta Laibacher Zeitung in I.julljanski zvon. Upoštevajoč tedanje razmere in okoliščine je namen članka podati predvsem strukturni prerez repertoarjev obeh gledališč, ne pa same kvalitete izvedenega, saj so ocene predstav zaradi nacionalnega momenta vprašljivo objektivne in zato med seboj težko primerljive. with the Slovene counterpart. On both sides, operatic premieres have been in the forefront of interest, accompanied by critical echoes in relevint local periodicals, such as the Laibacher Zeitung and the Ljubljanski zvon (The Ljubljana Bell). Taking into account the then prevailing conditions, the article aims at giving a structural profile of the repertoires of both theatres, leaving out the question of quality, since, due to the national factor, an objective evaluation of individual performances appears to be questionable and mutually comparable.

Dne 16. februarja 1887 je ogenj do tal uničil zgradbo Deželnega gledališča in s tem povsem ohromil glasbenogledališko življenje tedanje Ljubljane. Višja sila je kruto prekinila eno dotlej najpestrejših in najbogatejših opernih sezon pod vodstvom Juliusa Schulza ${ }^{1}$. Niti slovensko gledališče, ki je na čitalniškem odru nemoteno delovalo naprej, niti občasna gostovanja nemških družin, ki so sprva uprizarjala na odru deželne redutne dvorane nato pa na obnovljeni stekleni verandi Casina, vse do sezone 1892/93 niso mogla naclomestiti dogajanja, kakršnega je Ljubljana poznala prej. Otvoritev novega gledališča je bila šele pet in pol let po tragičnem dogodku, nova stavba pa je postala tudi stalni dom slovenske odrske reprodukcije. Slovenskemu gledališču, katerega uprizoritve so bile na sporedu redno dvakrat tedensko, je 29. septembra 1892 pripadla tudi častna otvoritvena predstava. Tako se je začela vedno bolj enakovredna vzporedna pot dveh nacionalnih glasbenih gledališč, ki sta se med seboj pomembno clopolnjevala.

\section{Nemško gledališče}

Gostujoče nemške družine so odrsko življenje $v$ novem "Landschaftliches Theater" kmalu vrnile na stare tirnice. Repertoar glasbenih del je bil - kot je bilo značilno že za večino sezon pred požarom - prežet predvsem z lahkotnimi operetami, razmeroma bogat pa tudi z opernimi predstavami. 
Vsako sezono je gledališko vodstvo vključilo vsaj tri ljub]janske operetne premiere², železni repertoar pa so tvorila predvsem clela Suppéja, Offenbacha, Millöckerja, Zellerja in Straußa, katerim so se na prelomu stoletja pridružili še Ziebrer, Reinhard, Lehâr in drugi. Med novo uprizorjenimi operetami so še posebno navdušile: Zellerjevi uspešnici Der Vogelhändler in Der Obersteiger; težko pričakovana Straußßova noviteta Jabuka, das Apfelfest; Suppéjeva zadnja opereta Das Modell; Der Opernball, edina uspešnica Richarda Heubergerja; Die Geischa, katere mednarodnega uspeha britanski avtor Sidney Jones ni več ponovil; ter Die Landstreicher avtorja Carla Michaela Ziehrerja.

$\mathrm{V}$ prvem deseteletju je nemško gledališče ljubljanskemu občinstvu predstavilo tudi deset novih opernih uprizoritev, največ prav v prvih sezonah izbranega obdobja. Že prva sezona pod vodstvom Rudolfa Frinkeja je ponudila dve ljubljanski premieri: Wagnerjevo Lohengrin (1850) in Neßlerjevo Der Trompeter von Säkkinger (1884). Poleg Gounodove Margarethe (Faust), Halevyeve Die Jüdin (La Juive) in Meyerbeereve Die Hugenotten (Les Huguenots) sta bili uprizorjeni po končani letni gledališki sezoni v okviru gostovanja operistov iz Celovca pod vodstvom umetniškega vodje Franza Eglsserja. Predvsem Lohengrin, ki je bil ponovno na repertoarju nemškega gledališča šele v sezoni 1906/07, je predstavljal pomemben kulturni clogodek, na katerega je $\mathrm{v}$ dnevnem časopisu Laibacher Zeitung opozoril tudi tedanji kritik Julius Ohm-januschowsky³. Ta sicer ni spregledal nepripravljenosti občinstva, vajenega lahkotnejše glasbe, čigar sprejemljivost naj bi imela svoje meje, vendar je prav zato pozdravil izvedbo "eines edleres Kunstwerkes ${ }^{4}$. Kritika je vseskozi upoštevala težavnost vseh izvedb, ki se je skozi celotno gostovanje kazala predvsem $v$ združevanju tujega ansambla in domačega orkestra, katere naj bi gostujoči dirigent Krones uspešno reševal. Tudi uprizoritev Lohengrina naj bi bila uspešna še posebno po zaslugi odličnih solistov, ki naj bi se z vidno vnemo in po najboljših močeh predali svojim težkim vlogam in jih uspešno realizirali. ${ }^{5}$

Frinke je s svojim ansamblom ostal v Ljubljani tudi naslednjo sezono, ki je bila tokrat $\mathrm{z}$ operami še bogatejša, ponudila pa je le eno ljubljansko premiero - Leoncavallovo Der Bájazzo (I Pagliacci). Ta je v tej sezoni doživela kar osem repriz in s tem potrdila nesluten uspeh prve predstave, ki jo je kritika pospremila $\mathrm{z}$ mnenjem, da je bila ena najboljših, kar si jih je bilo do tedaj v gledališču moč ogledati. Uprizoritev te opere priča tudi o težnji ljubljanskega nemškega gledališča, da bi, v okviru zmožnosti, sledilo novim smernicam tedanjih vodilnih opernih hiš. To $\mathrm{mu}$ je z Leoncavallovo enodejanko nedvomno uspelo, saj je bila njena krstna predstava $\mathrm{v}$ Milanu maja 1892, torej le dobro leto poprej. Iz kritike je razvidno, da je bila ljubljanska premiera velik in težko pričakovan dogodek, vendar pospremljen $\mathrm{z}$ določeno mero skepticizma. Ta se je izkazal za nepotrebenega, saj sta občinstvo očitno očarala napeto dogajanje in čudovita lepota glasbe. ${ }^{\prime} \breve{S}$ isto sezono se je obetala tudi nova uprizoritev drugega

2 V Ljubljani prvič izvedene operete v prvem desetletju obstojił noweğ gledališča so bile: v sezoni 1892/93 Der Vogelhändler (Carl Zeller), Der Viceadmiral, Das Sonntagskind, Die sisben Schwalxen in Der Feldprediger (vse stiri Millöcker), Die Uhlanen (Carl Weinberger); $\mathbf{v}$ sezoni 1893/94 Die lachende Erbe (Weinberger), Der Hofnarr (Adolf Müller) in Der Obersteiger (Zeller); v sezoni 1894/95 Jabuka, das Apfelfesi in Fürstin Ninetta (olse Strauß), Pariser Leben (Offenbach) in Der P'robekuss (Millöcker); v sezoni 1895/96 Capitän Nicol (Zeller), Die Karischülerin (Weinberger), Die Chansonetten-Sängerin (Rudoll 1)ellinger), Der Waldmeister (Strauß) in Der Figaro bei Hof (Adolf Müller); v sezoni 1896/97 Das Modell (Suppé) in Der Zauberer von Nil (Victor Herbert); v sezoni 1897/98 Der Wunderknabe (Eugen von Taund), Sataniel (Adolf Ferton), Die nümberger Puppe (Adolf Adam), Pagenstreiche ter Die Blumen-Mary (obe Weinberger), Der Pumpmajor (Alexander Neumann), Die Lieder der Mirza Schapfy (Louis Roth), Der Schelm von Bergen (Alfred Oelschlegel) in Die kleinen Schäfchen (Louis Barney); v sezoni 1898/99 Farinelli (Zumpe), Dor Opernball (kichard Heuberger), Die Glücksengel (Edmond Audrau), Der sclłöne Rigo (Ziehrer) in Die Gejscha (Jones); v sezoni 1899/1900 Der Lieutenant zur See (Roth), Ihre Excellenz (Heuberger) in Die Blondin von Namur (A. Müller); v sezoni 1900/01 Wiener Blut (A. Müller), Die Puppe (Eclmond Audran) in Die Landstreicher (Ziherer); v sezoni 1901/02 Mam'selle Nitouche (Ronger Hervé), Die drei Wünsche (Ziehrer), Sin Toy (Jones) in Das süsse Mädel (Heinrich Reinhardt); v sezoni 1902/03 Der liebe Schatz (Reinhardi), Der Rastellsinder in Wiener Fratuen (olbe Lehár).

1 Januschowsky, ki je s Casopisom sodeloval vse do 1 . svelovne vojne, je bil brat operne primadone Georgine von Januschosvsky, ki je $v$ Lijubljani tudi gostovala.

plementiega intmiska dela.

Laibacber Zeitung 18931 , št. 77.

Laibacher Zuitung 1893 II, št. 280. 
dejanja Wagnerjevega Der fliegende Holländer, a je bila ta zaradi bolezni napovedane gostje, dunajske dvorne operne pevke Georgine von Januschowsky, odpovedana. Wagnerjeva mojstrovina je tako doživela svojo prvo ljubljansko izvedbo šele v sezoni 1899/1900 v okviru slovenskega gledališča ${ }^{7}$.

Naslednje tri sezone so potekale pod direkcijo Adolfa Oppenheima, prinesle pa so zgolj nekaj opernih predstav. Medtem ko je bila $v$ sezoni $1894 / 95$ izvedena le Humperdinckova opera Hänsel und Gretel (1893), ki je po premieri doživela še pet repriznih uprizoritev, pa v naslednji sezoni ni bilo na sporedu niti ene opere. Humperdinckova pravljična opera je doživela prepričljiv uspeh, saj je kritika poročala o odličnem delu prave umetniške vrednosti in bila pravilno prepričana, da bodo sijajnemu uspehu sledile še številne, prav tako uspešne uprizoritve. Posebna hvala je poleg uspešnih solistov pripadala tudi orkestru, katerega vodstvo je z novo sezono prevzel dirigent Fritz Hempl, ki naj bi ohčinstvo očaral že z ognjevito, $z$ zagonom in zanesljivostjo odigrano predigro. ${ }^{*}$

Sezona $1896 / 97$, z operami neprimerno bogatejša, je posebno razveselila, kajti "...J obne Oper läßt sich ein Kunstinstitut von Bedeutung scbwer denken ${ }^{9}$ " Pripravili so tudi dve novi operni uprizoritvi: v ljubljanskem gledališču so zelo uspešno prvič izvedli Kienzlovo glasbeno igro Der Evangelimann in Goldmarkovo opero Das Heimchen am Herd, ki sta prišli na slovenski oder kmalu po krstnih izvedbah $(1895,1896)$. Posebno pozornost je kritika namenila wagnerjanskemu Evangeliku. Začetek sezone z duhovitim, ganljivim delom, eno najboljših novitet tistega časa, se je zdela posrečena ideja, ki je po mnenju pisca kazala na umetniško izkušenost direkcije. V obeh predstavah je vse priznanje ponovno požel orkester - prvič ga je vodil dirigent Henry Walther, drugič pa Max Groß. Svoje vloge pa naj bi odlično izvedli tudi solisti. ${ }^{10}$ Omeniti velja še izvedbo Beethovnovega Fidelia, ki je bil na odru nemškega gledališča le redko uprizorjen ( $\mathrm{v}$ Ljubljani sploh prvič v sezoni 1873/74, nato pa do 1 . svetovne vojne le še v sezoni 1903/04). Predstavo je kritika zaradi mnogih težav, s katerimi se je spopadalo gledališče, sprejela razumevajoče. ${ }^{11}$

Z operetami bogata sezona 1897/98 ljubljanskemu občinstvu ni ponudila niti ene operne predstave, direkcija Franza Schlesingerja pa je trajala še naslednjo sezono, s katero je postal operni repertoar nemškega gledališča bogatejši za dve deli. Operni ansambel je namreč izvedel Puccinijevo Die Boheme (La Boheme, 1896) in danes popolnoma neznano Maro (1893), najuspešnejšo med sedmimi operami sklaclatelja Ferdinanda Hummla ${ }^{12}$. Posebno pozornost je seveda pritegnila Puccinjeva stvaritev. Odlična uprizoritev je naletela na nadvse pozitivno, v značaj samega dela poglobljeno kritiko, ki je tudi tokrat hvalila prizadevno vztrajnost in umetniško izvedbo celotnega ansambla, kapelnikovo vodenje orkestra in soliste. ${ }^{13}$ Odmevna je bila tudi izvedba Mare, ki sledi vzorcem verističnih oper Cavalleria Rusticana in I Pagliacci. Kritika te enodejanke je vseskozi upoštevala okoliščine provincialnega gledališča: "Da wir nun von unseren sonst so braven Operettenkräften die künstleriscben Eigenschaften dramatischer Sänger ersten Ranges unmöglicb fordern können, erscheint es überflüssig, einen kritiscben Maßstab an ibre Liestungen anzulegen." ${ }^{1 . i}$ Vodstvo orkestra je v tej sezoni prevzel dirigent Karl Auer, ki je prav tako požel veliko pohval. ${ }^{15}$

7 Nemci so to opero $v$ Ljubljani prvič uprizorili sele $v$ sezoni $1904 / 05$.

* Laibacber Zeilung 1895 1, št. 15.

9 -brez opere je kulturna instilicija kežko pomembna."

10 Laibacber Zeillung $1896 \mathrm{II}$, st. 235.

1 Laibacber Zeilung 1896 II, st. 261.

12 Ferdinand Hummel (1855-1929) je bil nemsiki skladalleli in harfist, cigar opus obsegat okoli 120 del.

13 Laibacber Zaitumg 1898 II, št. 287.

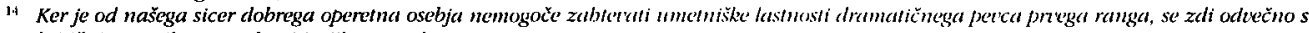
kritičntm merilom oured notiti njibot nezullat.

15 Laibacber Zeitumg 1899 l, št. 64. 
Podobno zasnovan je bil repertoar tudi $v$ naslednjih sezonah. Prevladovale so operete, operne izvedbe pa so bile prej izjema kot pravilo, kar glede na izrazito operetni sestav ansambla ne preseneča. Do izteka prvega desteletja obstoja novega Deželnega gledališča so bila na novo predstavljena vendarle še tri dela. Sezona 1899/1900 je pod vodstvom Karla Dietricha ponudila dve ljubljanski premieri: $\operatorname{Karin}^{16}$ (1888), katere avtor Herman Zumpe je bil svoj čas priznan dirigent predvsem Wagnerjevih del, ter danes prav tako neznano opero Enoch Arden ${ }^{17}$ skladatelja Victorja Hausmanna. Prva že tedaj ni doživela nikakršnega zanimanja in še manj uspeha, saj naj bi pomanjkanje sloga - nihanje med romatnično opero in trivialno operetno glasbo - učinkovalo povsem nezadovoljivo. ${ }^{18}$ Nekoliko odmevnejša je bila uprizoritev dela Enoch Arden, uspeha pa je bil deležen predvsem dirigent Cámillo Hildebrand, ki je doživel lep uspeh, topel sprejem in buren aplavz. ${ }^{19}$

Vodstvo gledališča je $v$ zadnjih treh sezonah izbranega obdobja prevzel Berthold Wolf ( $v$ Ljubljani je ostal vse do konca sezone 1908/09) in postopoma zopet obogatil operno življenje tedanje Ljubljane. Prva operna predstava nove direkcije je bila sicer šele v sezoni 1901/02, edino delo na sporedu pa je bila nova uprizoritev Offenbachove fantastične opere Hoffmanns Erzählungen (Les contes d'Hoffmann, 1881), ki je doživela še pet repriznih izvedb. Omembe vreden dogodek sezone, ki naj bi ga občinstvo pričakovalo z veliko napetostjo, direkcija pa $\mathrm{z}$ velikim upanjem, je bil po mnenju kritika nadvse uspešen, njegovega priznanja pa so bili deležni tako solisti kot orkester pod vodstvom dirigenta Siegfrieda Theumanna. ${ }^{20}$ Zadnja sezona 1902/03 prvega desetletja obstoja novega Deželnega gledališča sicer ni prinesla nobene novosti $v$ njegovem repertoarju, $z$ uprizorjenimi osmimi različnimi opernimi deli pa je bila ena bogatejših $\mathrm{v}$ tem obdobju.

\section{Slovensko gledališče}

Nasprotno od že uveljavljenega, z bogato tradicijo in lastnim orkestrom opremljenega Nemškega gledališča, je slovensko gledališče $v$ tem obdobju delalo šele prve operne korake. $Z$ uprizoritvami lahkotnejših zvrsti - spevoigre in operete - segajo začetki glashenogledališkega življenja že v sezono 1868/69, izvedba Blodkove V vodnjaku (V studni), 25. 3. 1889, pa je pomenila prvo slovensko operno predstavo. Slovensko gledališče je dobilo prave pogoje za reprodukcijo operne zvrsti šele z otvoritvijo novega Deželnega gledališča, ki so jil Slovenci izkoristili do skrajnih meja svojih zmožnosti. Nasprotno od repertoarja nemškega gledališča pa Slovenci na spored niso vključili veliko operet. Število uprizorjenih del te zvrsti ni preseglo štirih različnih operet na sezono, v sezonah 1893/94 in 1895/96 pa ne zasledimo celo nobene. ${ }^{21}$ Slovensko vodstvo se je očitno osredotočilo na občinstvu mikavnejšo opero, četudi pogosto lahkotnejšega značaja.

Že prvo sezono so bile na sporedu tri opere: poleg zopet uprizorjene V vodnjaku še krstna predstava Ipavčevih Teharskih plemičev²2 in ljubljanska premiera Mascagnijeve Cavallerie

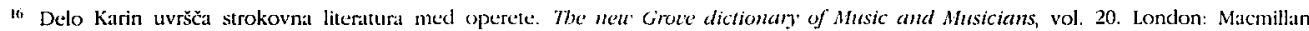
publishers limited, 1980 , str. 715.

17 Leta 1936 je napisal istoimensko opero Ottmar Gerster (1897-1969), ki je živa še danes.

is Laibucher Zaitung 19001 , št. 53.

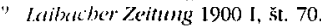

4) Laibucber Zeitım 1902 II, šs. 1.

21 V izbranem desetletju so bile uprizorjene naslednje operete: Mannschaft am Bord in Somnambule (obe Ivan Zajc), Cannebas, Zehn Mädchen und kein Mann ter Die schöne Galathee (vse tri Suppé), Le mariage aux laternes, La belle Helene in La violoneux (vse tri Offenbach), Mam'selle Nitouche (Ronger Hervé), Les 28 jouirs de Clairette (Victor Roger), Die Fledermaus (Strauß) in Amaconke (Parma).

22 Kritika la krstni izvedłbi lirične opere Telarski plemič, ki jo je izjemoma napisal Januschowsky, predlaga oznako Singspiel, saj naj bi delu manjkale glavne značilnosti opere: oblika, tehnika in prekomponiranost. Laibacber Zeilung 1892 11, št. 282.
} 
Rusticane $^{23}$. Iz kritike $v$ Laibacher Zeitung ${ }^{24}$ je razvidno, da je bila prva izvedba Teharskih plemičev nadvse uspešna. Burne ovacije so bile namenjene skladatelju, "...J der sich auf dem Gebiete der nationalen Kunst große Verdienste erworben und sein redliches Streben durch neues Schaffen bekundete. ${ }^{25}$ "Za uspeh so bili zatslužni tudi dirigent Fran Gerbič s temeljitim študijem ter vsi solisti. ${ }^{26} \mathrm{Z}$ veliko napetostjo ter razumljivo tudi $z$ določeno mero skepticizma pa naj bi slovensko občinstvo pričakalo tudi Cavallerio rusticano, katere uprizoritev je pomenila " $/ . . . /$ bei unseren bescheidenen Verbältnissen ein Wagestück erstes Ranges. ${ }^{27}$ Kritiko je izjemno presenetila, zopet zaradi popolne požrtvovalnosti dirigenta. Na splošno je značilno, da je ocena posameznil opernih izvedb - in tudi te - upoštevala okoliščine in razmere, zato od predstave niso pričakovali brezhibnosti in popolnosti. Kljub številnim nepravilnostim je tako Cavallerio pozdravila kot razveseljiv dokaz, da se lahko laskav uspeh doseže tudi z domačimi močmi in $\mathrm{v}$ pogosto neugodnih razmerah. ${ }^{28}$

V naslednjih letih je število opernih predstav naraščalo, gledališko vodstvo pa je poskrbelo, da je vsaka sezona ponudila tudi nekaj novih uprizoritev slovenskega odra. Mnogo je bilo sicer starih del, ki so bile občinstvu nemškega gledališča že dobro poznane: Prenočišče v Granadi (Das Nachtlager von Granada), Čarostrelec (Der Freischütz), Trubadur (Il trovatore), Afričanka (L'Africaine), Faust, Norma, Rigoletto, Fra Diavolo, La Traviata, Ples v maskah (Un ballo in maschera), Vesele žene windsorske (Die lustige Weiber von Windsor), Lohengrin, Glumači (I pagliacci), Alessandro Stradella, Favoritinja (La favorite), Viljem Tell (Guillaume Tell), Hoffmanove pripovedke (Les contes d'Hoffmann). Zato so bile zanimivejše tiste, ki so bile $\mathrm{v}$ Ljubljani prvič predstavljene: po eni strani opere slovanskih skladateljev, ki niso bile uvrščene na repertoar nemškega gledališča, po drugi pa dela iz zahodnoevropske operne zakladnice, ki jih do tedaj ljubljansko nemško gledališče še ni uprizorilo (poleg že omenjene Cavallerie še Verdijeva Aida ${ }^{29}$, Wagnerjev Večni mornar (Der fliegende Holländer) in Asrael skladatelja Alberta Franchettija ${ }^{30}$ ). Med slovanskimi premierami imajo seveda posebno mesto dela domačih skladateljev, ki so se z boljšimi pogoji in načrtno stimulacijo gledališkega vodstva številčno počasi množila.

V sezoni 1893/94 so si ljubitelji opere prvič lahko ogledali uprizoritvi Bendlovega Starega ženina (Star" ženich, 1882) in Smetanovo Prodano nevesto (Prodaná nevista, 1870). Obe premieri sta pred povsem razprodano dvorano doživeli sijajen uspeh, ki ga je kritika zopet pripisala celotnemu ansamblu, tokrat pa izpostavila tudi zloor. Še posebej je bila $v$ ospredju Smetanova svetovna uspešnica, dogodek, ki naj bi z vso jasnostjo zaznamoval razveseljiv vrhunec nacionalnega gledališča. Premiera naj bi namreč, zahvaljujoč požrtvovalnosti Dramatičnega društva in občudovanja vredni vztrajnosti dirigenta Gerbiča, potekala najboljše možno. ${ }^{31}$

Naslednjo sezono sta iz pestre in še številčnejše množice opernih predstav izstopali ljubljanska premierna izvedba Smetanovega Poljuba (Hubička, 1876) in krstna uprizoritev izvirne opere Urh, grof celjski Viktorja Parme. Izvedba ctrugega Smetanovega dela naj bi bila glede na obstoječe razmere nadvse uspešna. Razumevajoča kritika je upoštevala težavnost dela,

\footnotetext{
23 Opero je Nemško gleclališ̀ce premiemo uprizorile šele v sezoni 1903/04.

2.1 Kritike predstav slovenskega glechališca so z otvoritvijo novega gledališca postale v Laibacher Zeitung redne. Avtor večine teh je bil podpisan $\mathrm{z}$ inicialko $-\mathrm{n}$.

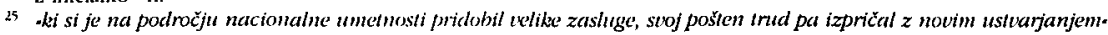

26. Laibacber Zeillung 1892 II, št. 284 .

27. za naše skromne razmere dogodek precega runga*.

24. Laibacber Zeitı!ng 1893 I, št. 32.

29. Nemško vodsrvo je Aido prvič uvrstilo na svoj repertoar v sezoni 1904/05

30 Gre za Franchettijevo (1860-1942) prvo opero, ki je bila krsino uprizorjena 1889 v milanski Scali.

31 Laibacher Zeitung 1894 I, šı. 80.
} 
predvsem orkestrskega pasusa: da bi bile izražene vse njene nežnosti in fine nianse, terja namreč opera vseskozi napeto koncertno obdelavo; zato $\%$...J dies Übelstände, die durch den Drang der Verbältnisse entscbuldigt werden mögen ${ }^{32} .{ }^{33}$ Toliko bolj so navdušili solisti, ki so se izkazali tudi $\mathrm{v}$ premierni uprizoritvi Urha, $\mathrm{v}$ kateri je ocena ${ }^{3 / 4}$ predstave poudarila rezultat orkestra pod vodstvom dirigenta Beniška ${ }^{35}$.

Številne premiere slovenskega gledališc̆a so se vrstile tudi $v$ naslednjih, z opernimi deli izredno bogatih in pestrih sezonah, ko se je ansambel slovenskega gledališča spopadal z vedno novimi in vedno večjimi izzivi, uspeh pa je bil - razumljivo - odraz stanja slovenskih glasbenogledaliških razmer. Na repertoar sezone 1896/97 sta bili med drugim zopet uvrščeni dve krstni izvedbi: prvi je bil Foersterjev Gorenjski slavček, tokrat prvič izveden kot komična opera ${ }^{36}$, druga pa Parmova Ksenija. Obe premieri sta doživeli velik uspeh, zasluge zanj pa je kritika pripisala v prvi vrsti nadvse uspešnemu in sposobnemu Benišku, pa tudi solistom in zboru.

$S$ to sezono pa se je končalo redno poročanje o izvedbah slovenskega gledališča $v$ Laibacher Zeitung. Zakaj je anonimni kritik prekinil sodelovanje z dnevnim časopisom, ni znano. Tako je zgodovinski vpogled v slovensko gledališko dogajanje $v$ Ljubljani ostal navezan na Ljubljanski zvon. Tu poročila sicer niso bila tako redna, kljub temu pa iz njih izvemo bistvene značilnosti opernih uprizoritev. Za bogato sezono $1897 / 98$ je kritika ${ }^{37}$ poročala o edini premierni predstavi slovenskega gledališča v tej sezoni, nadvse uspešni uprizoritvi opere Halka (1854) poljskega skladatelja Stanislawa Moniuszka ${ }^{38}$, katero je označila kot neovržen dokaz, da so Poljaki ostali pravi Slovani. Pohvalila je tudi izvedbo samo, saj naj bi pevci peli le malokdaj s takim navdušenjem ter igrali $s$ tako vnemo. ${ }^{39}$

Tudi naslednja sezona je prinesla eno krstno izvedbo, Parmovo dramatično romanco Stara pesem. Bolj $\mathrm{v}$ ospredju zanimanja pa je bila uprizoritev Wagnerjevega Lohengrina, prvič izvedenega $v$ okviru slovenskega gledališča. Po mnenju kritike bi morali dan, ko so opero uprizorili, v kroniki gledališča debelo podčrtati. Ocena o izvedbi, ki se omejuje predvsem na osnovne značilnosti dela samega, priča o zavedanju pisca o pomembnosti dela nemškega mojstra, hkrati pa izkazuje njegovo nedoraslost glasbeni drami, saj pravi: "Prijetno je to zvenenje in tudi mamljivo za ubo, a ne prodira nam v srce . $_{\text {. }}{ }^{(0)}$ Poleg tega je bila $\mathrm{v}$ tej sezoni prvič $\mathrm{v}$ Ljubljani izvedena Verdijeva Aida, $\mathrm{z}$ umetnico in primadono Zagrebškega gledališča L. Brucklovo v premierni predstavi.

S sezono 1899/1900 se je zamenjalo vodstvo Dramatičnega društva, katerega prvi korak je bila zamenjava vseh opernih solistov. Drzna poteza se je izkazala za zelo dobro, saj naj bi bile vse predstave nadvse uspešne, glavne zasluge pa je dr. Vladimir Foerster ${ }^{-1}$, ki je v tej sezoni prevzel poročila opernih predstav, pripisal ponovno Benišku, ki "/... uspešno vodi slovensko opero z rutino in smelo odločnostjo." ${ }^{42}$ Bogata glasbena sezona je tudi tokrat prinesla eno novo uprizoritev, Smetanovega Daliborja (1868), katerega izvedba naj bi pomenila vsekakor velik korak do novega napredka. ${ }^{43}$ Po 33 letih delovanja Dramatičnega društva je bila v tej sezoni

32 ... "labko zaradi pritiska okolišcin te pomankljitosti oprostimo."

33 Laibacber Zeitung 1894 II, št. 264.

in Laibacber Zeitumg 1895 I, št. 40.

15 Hilarius Benišck je vodstvo orkestra prevzel konec novembra 1894, funkcijo dirigenta pa je v tej sezoni opravljal izmenično z Gerbičen.

*w O Gorenjskem slavčku je pred krstno izvedbo predelane verzije pisal tudi kritik predstav ljubljanskega nemškegal gledališča Janıschowsky. Latbacber Zeinung 1896 II, šr. 229.

5. Za naslednji dve sezoni je bil pisec gledaliških ocen v Ljubljanskem zvonu podpisan z inicialko - z; najverietneje gre za dr. Zbašnika, ki je kritike - predvsem clamske - prevezel zopel $v$ sezoni 1902/03.

4i. Sianislaw Moniuszko (1819-1872) velja - tako kot Glinka v Rusiji in Smetana na Ceškem - 7a utemeljitelja poljske naciolnalne opere. limbljuliki ztom 1898, str. 126-127.

ljubljanshi zton 1899, str. 255-256.

1 S Foersterjem so kritke postale tehtnejše in izčrpnejiše ter nudlijo jasnejǒso predstavo o izvedbah samih.

+2 Ljubljanski suon 1899, str. 710.

if liubljanski zton 1899 , str. 768 . 
odigrana tudi jubilejna tisoča predstava in to prav z Wagnerjevim Večnim momarjem (1843), ki je bil v Ljubljani tokrat sploh prvič izveden. Uprizoritev opere, ki je bila "usekakor znamenita", naj bi bila tudi nadvse uspešna. ${ }^{44}$

Za naslednjo sezono v Ljubljanskem zvonu ni nobene objavljene kritike. Škoda, saj je pestra operna sezona prinesla ne le ljubljansko premiero Zajjčeve opere Nikola Šubič Zrinski (1876) temveč tudi novo uprizoritev iz Wagnerjevega opusa, tokrat opero Tannhäuser $(1845)^{45}$. Sklepamo lahko, da je bilă uspešna, saj je premieri sledilo še pet repriznih uprizoritev, pa tudi izvedba $v$ prihodnji sezoni naj bi zelo dobro uspela. ${ }^{46}$

Sezona 1901/1902 je novosti željnemu občinstvu ponudila še eno krstno predstavo, in sicer Smiljano skladatelja Frana Serafina Vilharja. Izvedlaa naj bi presenetila celo navzočega avtorja samega. Po mnenju Lavoslava Pahorja, kritka Ljubljanskega zvona za operne predstave $\mathrm{v}$ tej sezoni, je bila dobro naučena in je sijajno uspela, solisti, zbor in orkester pa so dobro rešili svojo nalogo. Kritik je izrecno poudaril tudi pomen uprizoritev Halevyeve Židinje (La Juive) in Bizeteve Carmen, ki sta pričali o uspehu in napredku. ${ }^{17}$

Zadnja sezona prvega desetletja delovanja novega deželnega gledališča je upoštevala javno pripombo glasbenega kritika, da "...l se pri sestavi repertoarja za bodočo sezono jemlje več ozira na slovanske opere ${ }^{18}$; poleg Prodane neveste in Daliborja sta bili tako na sporedu krstna izvedba lirične opere Maričon Srečka Albinija in ljubljanska premiera Psoglavcev (Psohlavci, 1898) Karla Kovašovica. Predvsem slednja je pritegnila veliko pozornosti. Strokovno oceno predstave je podal dr. Vladimir Foerster. Upoštevajoč težke razmere orkestra, saj "/...] majben orkester pa seveda ne zadostuje moderni operi, je posebno pohvalil na novo postavljen solistični ansambel in ga samozavestno postavil ob bok večjim odrom. V ospredju pa je bil zopet Benišek, ki naj bi skupaj z dramatičnim odborom dosegel uspeh, ki ga je bilo iskreno pohvaliti. ${ }^{19}$

Prvo desetletje novega Deželnega gledališča je bilo torej pestro in razmeroma bogato. Težnje in prizadevanja nemškega in še posebno slovenskega vodstva so se manifestirale v barvitem, med seboj dopolnjujočem repertoarju. Na nemškem odru se je v tem obdobju zvrstilo kar nekaj pomembnih ljubljanskih premier. Gostujoči operisti iz Celovca so ljubljanskemu občinstvu prvič predstavili Wagnerjevega Lohengrina, do tedai šele drugo opero iz opusa nemškega reformatorja. Ljubljana je spoznala tudi Leoncavallove veristične Glumače, ki so nedolgo nazaj doživeli krstno uprizoritev, ter še prav tako svežo Humperdinckovo pravljično opero Janko in Metka. Kar nekaj let je nato minilo do uprizoritve Puccinijeve stvaritve La Boheme, ki je luč sveta ugledala le dve leti pred ljubljansko premiero. Pred iztekom prve dekade je nato vodstvo nemškega gledališča uvrstilo na spored le še eno novost, Offenbachove Hoffmanove pripovedke, ki so na drugih gledaliških odrih že dvajset let navduševale ljubitelje operne umetnosti.

Nedvomno bogatejša je bila ponudba Slovenskega gledališča. Z v Ljubljani prvič uprizorjenimi Cavallerio Rusticano, Aido in Večnim mornarjem so posegli v repertoar nemškega gledališča in ga s tem na nek način tudi presegli, dopolnili pa so ga s številnimi operami slovanskega izvora. Smetanova Prodana nevesta in Blodkova V vodnjaku sta postali del železnega repertoarja, Poljub, Dalibor, Bendlov Stari ženin, Halka poljskega skladatelja Stanislawa Moniuszka ter Kovašovicevi Pshoglavci pa popestritev bogatega opernega dogajanja. Še pomembnejše so bile krstne uprizoritve izvirnih opernih del domačih skladateljev: Ipavčevi Teharski plemiči, Parmovi Urh, grof celjski in Ksenija, Foersterjev Gorenjski slavček ter Vilharjeva Smiljana.

H limbliantwi zlon 1900, str. 193-194.

15 V skviru N'emškeğa gledališč je bila opera izvedena že v sezoni $1873 / 74$, nato pa do 1 . svetovne vojne ne več.

46. Ljubljauski zion 1902, str. 68 .

47 Ljubljanski zlon 1901, str. 791.

th Linbljanski zeon 1902, str. 284.

4) Liubljanski zion 1903, str. 125. 
O pestrosti glasbenega življenja na odru ljubljanskega gledališča priča že analiza obsega posameznih predstav. Značilne so številne reprize tistih del, ki so bila prvič uprizorjena pri nas. Iz povprečja nemških opernil izvedb, ki so največkrat doživele le po eno reprizo, tako izstopajo ljubljanske premiere Glumačev, s kar devetimi predstavami v eni sezoni, pa Janka in Metke ter Hoffmannovih pripovedk s po šestimi uprizoritvami. Veliko število ponovitev nedvomno potrjuje navdušenost kritike nad izvedbami. Drugačna slika se kaže na slovenski strani. Številne opere so navduševale iz sezone $v$ sezono, zato ne preseneča izredno visoka številka vseh uprizoritev v enem desetletju. Nasprotno od razvajenega in zahtevnega občinstva nemških predstav, ki so opernim predstavam prisostvovali že desetletja dolgo, so slovensko vodstvo, domači izvajalci in njim zvesta publika stali šele na samem začetku operne reprodukcije. Začetni entuziazem je bil tako povsem razumljiv, potreben in koristen za razvoj tako enih kot drugih.

Upoštevajoč tedanje razmere in okoliščine je primerjava repertoarjev obeh gledališč vendarle smotrna le s strukturnega vidika sporedov; sporno bi namreč bilo primerjati dejansko kvaliteto ponujenega, ne glede na obstoječe ocene posameznilh predstav. Že kritiki sami - pisci nemških ali slovenskih večerov - so upoštevali in poudarjali razmere provincialnega gledališča, ki zopet niso bile enake med enim in drugim gledališčem. Nadalje ne gre spregledati niti ravni objavljenih ocen; predvsem kritike v Ljubljanskem zvonu, razen tistih Vladimirja Foersterja, niso primerljive s strokovnimi ocenami nemških gledaliških predstav, kakršne je podajal Januschowski. Tehtni zapisi slednjega obsegajo tako značaj glasbenega dela kot tudi objektivno oceno same izvedbe. ${ }^{50}$ Večji nacionalni moment preveva, razumljivo, ocene slovenskih kritikov. Medtem ko si prizadevajo ocene slovenskih predstav $v$ Laibacher Zeitung doseči nivo Januschowskega, pa so tiste v Ljubljanskem zvonu daleč za njim. Čeprav skušajo biti objektivne tako glede samih izvedb kot dojemljivosti občinstva ${ }^{51}$, pa so le Foersterjeve tudi dovolj strokovno podkrepljene in pričajo o avtorjevem glasbenem znanju.

Vsekakor pa lahko zaključimo, da je tako ena kot druga nacionalna tirnica doprinesla $\mathrm{k}$ barvitosti glasbenogledališkega dogajanja tedanje Ljubljane. Nemci so skrbeli predvsem za kontinuiteto že uveljavljenega repertoarja, operne predstave pa zaradi sezonskega spreminjanja opernega ansambla in njegovih sposobnosti niso bile redno na sporedu. S tega vidika so prednjačili manj zahtevni Slovenci, ki so se že na samem začetku spopadli z uprizarjanjem oper. Tega niti Nemci niso spregledali ${ }^{2}$. Neobremenjena s tradicijo je slovenska direkcija postavljala prve temelje slovenski operni produkciji, hkrati pa se je morala prilagajati zahtevam javnosti - sprva se je kazala težnja po večji produkciji drame, pozneje so zahtevali več moderne in slovanske opere - ki so jo silile v nenehno dopolnjevanje in preoblikovanje. Pri tem je storila pomemben odmik od nemškega vodstva, saj je $v$ repertoar vključila ne le slovansko, ampak tudi slovensko operno produkcijo. Jasno postavljeni cilji, težnje in naloge so Slovence vodili $k$ naraščujoči prepoznavnosti in konkurenčnosti, zdrava tekmovalnost predvsem $v$ nacionalnem smislu pa je pospeševala umetniški razvoj tako ene kot druge nacionalne struje ter pripomogla $k$ vedno večji tehtnosti predstav, zlasti slovenskil.

so O objektivnosti njegovih kritik priča ne le podatek, da je Januschowsky tu in tam zapisal tudi (pozitivno) porcecilo preditave slovenskega gledališča (npr. ob premieri Teharskih plemičev), pač pa vsekakor tudi podatki, da je pisec med drugim dolga leta poučeval v glasbeni šoli Glasbene matice, vodil citalniski pevski zhor in zhor drušlva Slavec. Budkovič, Cvetko. Razeoj glashenega solstua na Slovenskem: Od začetka do nastanka konsentatorija. Ljubljana: Znanstveni institut FF, 1992, str. 203.

51 Zbašnik na primer porčxa ol koncu steone $1896 / 97$, da so bile operne predstave večinoma dobre, vendar naj bi bilo med njimi bistveno več slabših kot sezono poprej. Lfubljanski zeon 1897, str. 388.

52 Nemska kritika v laibacher Zeitung je nemreč v uvodu k poročlu o premierni predstavitivi Glumačev opozorila na uprizoritev Cavallerie, iz repertoarja pit je rizvidno, da gre lahko le za slovensko premierno izvedbo: - Wie seinerzeit die Glihoper Mascagni's, so bildete nicht

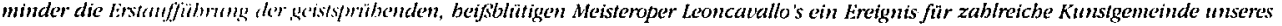

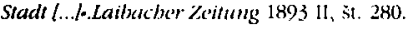

